\title{
Plasma zinc concentrations in iron supplemented low birthweight infants
}

\author{
G P SALVIOLI, G FALDELLA, R ALESSANDRONI, M LANARI, AND L BENFENATI
}

Institute of Neonatology and Preventive Pediatrics, Department of Pediatrics, University of Bologna, and Chemistry Laboratory, Bologna, Italy

SUMMARY We investigated the effect of prolonged iron supplementation of low birthweight infants on plasma zinc concentrations. Thirty infants (neonatal weight $820-2000 \mathrm{~g}$ ) were examined at 6 or 12 months of life to assess their iron state and plasma zinc concentration. All of them were feeding on iron fortified formulas, which supply about $1 \mathrm{mg} / \mathrm{kg} / \mathrm{day}$ of iron. In addition, 14 of them had been receiving $2 \mathrm{mg} / \mathrm{kg} /$ day of medicinal ferrous salts for at least five months. The other 16 were not given medicinal iron supplementation. Whereas iron state significantly differed in the two groups, plasma zinc concentrations were similar. Moreover, no zinc values below $75 \mu \mathrm{g} / 100 \mathrm{ml}$ were found in any case. The results suggest that long term iron supplementation of low birthweight infants, at the recommended doses, does not influence zinc plasma concentrations unfavourably.

Because of their proportionately smaller iron stores at birth and the increased demands of a more rapid rate of growth, low birthweight infants are particularly susceptible to iron deficiency. ${ }^{12}$ Hence they require iron supplementation during the first year of life to maintain a safe iron balance. Supplementation varies from 2 to $4 \mathrm{mg} / \mathrm{kg} /$ day, depending on neonatal weight, and can be achieved using iron fortified formulas or medicinal iron, or both. ${ }^{34}$ Recently, it has been suggested that poor zinc bioavailability ensues from non-haeme iron supplements, related to a competitive absorption interaction of zinc and iron. ${ }^{56}$ We therefore investigated the changes in plasma zinc concentration during iron supplementation of low birthweight infants.

\section{Materials and methods}

Thirty infants were studied (neonatal weight 820 $2000 \mathrm{~g}$ ). They were admitted to the neonatal unit because of their low neonatal weight. None of them needed intensive care. After discharge they were enrolled in a prospective follow up clinic, which had been in operation since January 1981. Each visit to the clinic included an interim history recall, a complete physical and neurological examination, clinical screening of the developmental state based on the Brunet-Lezine test, ${ }^{7}$ and an assessment of iron state. Starting from May 1984, at the fixed six month or one year (age corrected for gestational age $=40$ weeks) follow up visit, a venous blood sample was also obtained to assess plasma zinc concentration.

By the second month of life all the infants were being fed on a cow's milk adapted formula, containing $0.8 \mathrm{mg} / 100 \mathrm{ml}$ of iron and $0.5 \mathrm{mg} / 100 \mathrm{ml}$ of zinc. By 5-6 months of age they were being fed a follow up formula containing $1.2 \mathrm{mg} / 100 \mathrm{ml}$ of iron and 0.5 $\mathrm{mg} / 100 \mathrm{ml}$ of zinc. In addition, supplemental medicinal ferrous-sulfate iron at a dose of $2 \mathrm{mg} / \mathrm{kg} / \mathrm{day}$ (to a maximum of $15 \mathrm{mg} / \mathrm{day}$ ) was also prescribed. At the time of examination 14 infants (11 aged 6 months and three aged 1 year) had been receiving medicinal iron supplementation and iron fortified formula for at least five months (high dose iron supplemented group). The other 16 infants (12 aged 6 months and four aged 1 year) had stopped medicinal iron supplementation for at least three months and had only been receiving iron contained in the formulas, corresponding to about $1 \mathrm{mg} / \mathrm{kg} / \mathrm{day}$ (low dose iron supplemented group). The average (SD) weight of the 14 high dose infants was 1464 (437) $\mathrm{g}$ at birth, 7096 (1137) $\mathrm{g}$ at 6 months (age corrected for gestational age $=40$ weeks), and 9314 (1228) $\mathrm{g}$ at 1 year. At 6 months they had increased their weight by an average of $5 \cdot 1$-fold and at 1 year by $6 \cdot 3$-fold over birth weight, but the range of individual values was considerable, varying from 3.6- to 6.6-fold at 6 months and from 4.2- to 9.3-fold at 1 year. The average (SD) weight of the 16 low 
dose infants was 1785 (193) $\mathrm{g}$ at birth, $6772(1010) \mathrm{g}$ at 6 months, and $8969(883) \mathrm{g}$ at 1 year. Their individual variation in growth had ranged from 2.9to $6 \cdot 1$-fold over the birth weight at 6 months and from $4 \cdot 0$ - to $7 \cdot 9$-fold at one year.

Iron state was evaluated by means of measuring haemoglobin concentration, mean corpuscular volume, the ratio between erythrocyte porphyrin concentration and haemoglobin, and serum ferritin concentration. ${ }^{8}$ Normal values, at the age considered, are haemoglobin $\geqslant 110 \mathrm{~g} / \mathrm{l}$; mean corpuscular volume $\geqslant 70 \mathrm{fl}$; erythrocyte porphyrin: haemoglobin $\leqslant 3 \mu \mathrm{g} / \mathrm{g}$; serum ferritin $\geqslant 10 \mu \mathrm{g} / 1 .{ }^{3} 9$

Evaluation of haemoglobin concentrations and mean corpuscular volume were performed on a Model ZF Coulter Counter; erythrocyte porphyrin was determined fluorometrically on a ESA 4000 Hematofluormeter; and serum ferritin concentrations were measured by radioimmunoassay (Ramko Laboratories Inc, Houston, Texas, United States of America). Plasma zinc concentrations were determined by atomic absorption spectroscopy on a Model 4000 Perkin Elmer, according to the method of Smith and Butrimovitz, including procedures to avoid metal contamination. ${ }^{10}$ Informed consent was obtained from all the parents.

The statistical analyses were calculated using Student's $t$ test.

\section{Results}

The Table summarises the data on iron state and plasma zinc concentrations found in both high and low dose iron supplemented infants. All the values, except plasma zinc concentrations, significantly differ in the two groups. None of the high dose infants were found to be anaemic, whereas six $(37 \%)$ of the low dose infants were. While two $(13 \%)$ of the high dose group showed values of erythrocyte porphyrin:haemoglobin $>3 \mu \mathrm{g} / \mathrm{g}$ and one $(7 \%)$ values of serum ferritin $<10 \mu \mathrm{g} / \mathrm{l}$, in the low dose group these figures were nine $(56 \%)$ and six $(44 \%)$, respectively.

The plasma zinc values of each infant are shown in the Figure. The range of values is $75-180 \mu \mathrm{g} / 100 \mathrm{ml}$

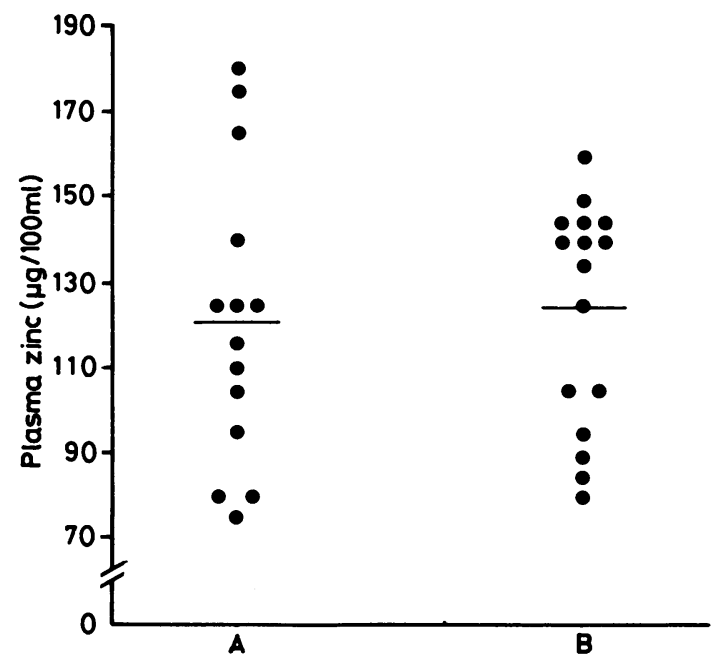

Figure Plasma zinc concentrations in 14 high dose (a) and 16 low dose (b) iron supplemented low birthweight infants. The horizontal lines are the means of the groups.

in the high dose group (a) and 80-160 $\mu \mathrm{g} / 100 \mathrm{ml}$ in the low dose group (b). These findings indicate that high dose iron supplementation affects iron state but not plasma zinc concentrations in low birthweight infants.

\section{Discussion}

Both iron and zinc are essential trace metals in humans. While they have different biological functions, they interact in their membrane transfer processes. ${ }^{11}$

Solomons and Jacob conducted studies on the effect of iron and zinc absorption in humans and found that oral administration of inorganic zinc and ferrous salts at a ratio of $1: 1$ slightly inhibited zinc absorption, while an iron:zinc ratio of $2: 1$ and $3: 1$ substantially inhibited zinc uptake. ${ }^{5}$ Craig et al evaluated plasma zinc concentration in full term healthy infants, aged 3-4 months, fed with different cow's milk formulas and found that plasma zinc

Table Mean (SD) values of haemoglobin, serum ferritin, and plasma zinc concentrations, mean corpuscular volume, and erythrocyte porphyrin: haemoglobin ratio in 14 high dose and 16 low dose iron supplemented low birthweight infants

\begin{tabular}{lccc}
\hline & High dose group & Low dose group & Student t test \\
\hline Haemoglobin $(\mathrm{g} / \mathrm{l})$ & $122(6)$ & $113(10)$ & $2 \cdot 94$ \\
Mean corpuscular volume $(\mathrm{fl})$ & $77 \cdot 5(3 \cdot 6)$ & $72 \cdot 4(7 \cdot 6)$ & $<\cdot 6 \cdot 005$ \\
Erythrocyte porphyrin:haemoglobin $(\mu \mathrm{g} / \mathrm{g})$ & $1 \cdot 8(1 \cdot 0)$ & $3 \cdot 6(2 \cdot 2)$ & $<\cdot 29$ \\
Serum ferritin $(\mu \mathrm{g} / \mathrm{l})$ & $21 \cdot 4(10 \cdot 8)$ & $13 \cdot 1(9 \cdot 3)$ & $2 \cdot 84$ \\
Plasma zinc $(\mu \mathrm{g} / 100 \mathrm{ml})$ & $121(34)$ & $125(25)$ & $2 \cdot 26$ \\
\hline
\end{tabular}


concentrations in infants using iron fortified formulas were significantly lower than those of infants using unfortified formulas. ${ }^{6}$ In our study there was no significant difference in plasma zinc concentrations between high and low dose iron supplemented low birthweight infants.

The major difference between our investigation and that of Solomons and Jacob is that theirs was an experimental study while ours was a clinical one. Our main aim was to verify whether the fairly large amounts of iron given to low birthweight infants during the first year of life could influence zinc nutrition in these infants unfavourably. Solomons and Jacob gave high doses of iron and zinc in free solution after an overnight fast to healthy adult volunteers and evaluated the secondary increment in plasma zinc concentration during the following four hours. We assessed plasma zinc concentrations in healthy infants receiving prolonged inorganic iron supplements in large amounts but adequate to their needs, together with fortified formulas and other baby food.

This procedural difference is important as it is well known that the presence of dietary compounds in the intestinal lumen may affect the interaction and mucosal uptake of trace metals. Moreover, as the net absorption of these elements depends on the amounts ingested and the bioavailability of the source as well as the demand for each metal, the latter factor may influence the competitive interactions between iron and zinc in the intestinal mucosa greatly. ${ }^{12}{ }^{13}$ To maintain optimal iron balance low birthweight infants need $2-4 \mathrm{mg} / \mathrm{kg}$ /day inorganic supplement. Even though this amount of iron provides an iron:zinc ratio $>1: 1$, the active absorption of iron in the proximal intestine may lower the iron:zinc ratio in the distal lumen to a level that is also favourable for zinc absorption. ${ }^{5}$

The lower demands for iron in the first months of life of term infants may account for the different effects of iron supplementation on plasma zinc concentrations found by us and by Craig et al. In fact, high concentrations of iron in formulas for full term, appropriate birthweight infants greatly exceed their need for iron and their propensity to absorb it during the first 3-4 months of life. Thus the persistently high concentrations of iron in intestinal segments may reduce mucosal zinc uptake directly because of a competition for ligands and inhibition of transport. In the following months of life iron supplementation is also recommended for full term infants. Another recent report found no evidence that zinc nutrition was compromised by iron supple- ments in healthy, full term, well nourished infants at 1 year of age. ${ }^{14}$

In conclusion, we failed to find any plasma zinc values below $75 \mu \mathrm{g} / 100 \mathrm{ml}$, either in the high or low dose iron supplemented groups. Plasma zinc concentrations are only partially indicative of the total zinc content of the body. The equivalent plasma zinc concentrations found, however, in both high and low dose iron supplemented infants, together with the absence of any clinical signs such as low weight gain or altered behavioural patterns related to zinc deficiency, show that long term iron supplementation of low birthweight infants at the recommended doses does not influence zinc nutrition unfavourably. Moreover, high dose iron supplementation is essential for such infants as shown by the haematological values found in this study.

\section{References}

1 Lundstrom U, Siimes MA, Dallman PR. At what age does iron supplementation become necessary in low-birth-weight infants? J Pediatr 1977;91:878-83.

2 Faldella G, Alessandroni R, Salvioli GP, et al. Lack of correlation between free erythrocyte porphyrin and serum ferritin values at birth and at 2 months of life in low birthweight infants. Arch Dis Child 1983;58:216-9.

3 Siimes MA, Jarvenpaa AL. Prevention of anemia and iron deficiency in very low birth weight (VLBW) infants. J Pediatr 1982;101:277-80.

4 Jansson L, Holmberg L, Ekman R. Medicinal iron to low birth weight infants. Acta Paediatr Scand 1979;68:705-8.

5 Solomons NW, Jacob RA. Studies on the bioavailability of zinc in humans: effects on heme and nonheme iron on the absorption of zinc. Am J Clin Nutr 1981;34:475-82.

6 Craig WJ, Balbach L, Harris S, Vyhmeister N. Plasma zinc and copper levels of infants fed different milk formulas. J Am Coll Nutr 1984;3:183-6.

7 Brunet O, Lezine I. Scala di sviluppo psicomotorio della prima infanzia. Firenze: OS, 1967

8 Dallman PR. New approaches to screening for iron deficiency. J Pediatr 1977;90:678-81.

9 Lundstrom U, Siimes MA. Red blood cell values in low-birthweight infants: ages at which values become equivalent to those of term infants. J Pediatr 1980;96:1040-2.

10 Smith JC Jr, Butrimovitz GP, Purdy WC. Direct measurement of zinc in plasma by atomic absorption spectroscopy. Clin Chem 1979;25:1487-91.

11 Worwood M. Iron and trace metals. In: Jacobs A, Worwood M, eds. Iron in biochemistry and medicine. London: Academic Press, 1974:336.

12 Voyer M, Davakis M, Antener I, Valleur D. Zinc balance in preterm infants. Biol Neonate 1982;42:87-92.

13 Turnbull A. Iron absorption. In: Jacobs A, Worwood M, eds. Iron in biochemistry and medicine. London: Academic Press, 1974:369.

14 Yip R, Reeves JD, Lonnerdal B, Keen CL, Dallman PR. Does iron supplementation compromise zinc nutrition in healthy infants? Am J Clin Nutr 1985;42:683-7.

Correspondence to Professor G P Salvioli, Istituto Clinico di Puericultura, Via Massarenti 11, 40138 Bologna, Italy.

Received 20 January 1986 